\title{
Impacts of Conceive-Design-Implement-Operate Knowledge and Skills for Innovative Capstone Project
}

\author{
https://doi.org/10.3991/ijoe.v15i10.10874 \\ Hanifah Jambari ${ }^{\bowtie)}$, Nurul Amalin Razali, Nur Hazirah Seth@Noh, Nurul Aini Mohd \\ Ahyan, Mohamad Rasidi Pairan, Jamilah Ahmad, Sharifah Osman \\ Universiti Teknologi Malaysia, Malyasia \\ hanifah-j@utm.my
}

\begin{abstract}
Nowadays, the competitions among countries to recruit engineering students as workers do not focus on talents, but also on the reserve of it. The advancement of education in engineering field plays a big part in enhancing comprehensive domestic strength because the scientific revolution will contribute to important modifications of the industrial landscape. Therefore, ConceiveDesign-Implement-Operate (CDIO) understanding and techniques are required for enhancing this field of education particularly for innovation of capstone project. Thus, this study was identified student knowledge and skills consist of teamwork, problem-solving, and communication skills of the CDIO in capstone project involved two faculties which are Faculty of Biosciences \& Medical Engineering (FBME) and Faculty of Electrical Engineering (FKE) at Universiti Teknologi Malaysia (UTM). Our respondents consist of 28 and 30 of third-year students from FBME and FKE respectively. Besides, this study also was identified the importance of the CDIO approach in the innovative capstone project. The method that used was a quantitative survey by using 5 Likert scale questionnaires. The average mean for all research questions indicated that the majority of respondents agreed that the CDIO knowledge and skills in the capstone project are important in engineering education. Hence, the engineering students must possess not only the skills such as teamwork, problem-solving, and communication but also needs more knowledge that helps them to employability and adapt to real-world engineering problems.
\end{abstract}

Keywords-CDIO, Skills, Knowledge, Innovation

\section{Introduction}

There are numerous factors of curriculum changes in higher engineering education, and this all focuses to create other options to the outdated programmed that consists of disciplinary abstract courses [1]. In order to have a higher chance of attracting future students, enhance preparing skills for professional exercise, decrease attrition and produce a maintainable growth, innovation, and job creation, the background is a much needed concept. It also helps in producing quality growth and the quality of the processes as well as the results of education. Nowadays, not only talents but in fact the reserve of talents act as the factor of competitions among countries. Engineering 
knowledge that support each of the industries is able to sustain as well as encourage stability and development of the economic sector. Besides, advancement of engineering field is a key factor in encouraging complete domestic influence and this is because of scientific revolution contributes to significant changes of the industrial organization [2]. Engineering education need to adjust to this change so that engineer's role in society can change. Rather than having a career for lower technological engineering, engineer in the future can work for knowledge based service economy.

The needs for educator of engineering background are in high demand. This is because these people face the challenge of creating a learning environment that also nurture corporate process abilities in addition to the technical set of skills [3], raise graduating students' qualities starting in the initial year of engineering courses [1]. When the practical understanding and abilities form the fundamental of engineering syllabuses [4], these are not the only abilities that is needed from an engineering graduate as this industry now sought after engineers who possess abilities which explore beyond merely the technical mastery [5] as well as including the practice of soft skills such as independent and teamwork. Employability skills and entrepreneurship are accompanied by generic skills can be achieved if holistic education with basic amenities such as teaching equipment must be up to date with the current industry and technology development [6]. Therefore, CDIO identifies the engineering education cannot be acquired in a short period of time and educators in every part of this field can study from practice anywhere else.

\section{Problem Background}

Engineering graduates should have several technical knowledge and skills that contribute to enhance and improve their role in business and society and also enable students to perform their work with professionalism and success. Students should have the knowledge and abilities for example; teamwork, communicating skills, solving problems and critical thinking where all these outcomes are present in the CDIO Syllabus outcome which is standard 2 [7].

According to Crawley et al. [8], where the new and global challenges that exist nowadays have proven that those skills are essential in order to improve and enhance an engineer's masterpiece. All the engineering courses are asked to produce innovative methods in order for their students to acquire soft skills in addition to the core and technical subjects. Teamwork is a vital skill for an engineer to possess as almost every tasks and projects will have the involvement of two or more professionals in a multidisciplinary line. With that being said, soft skills like man management and communicating skills are important for accomplishing objectives and aims effectively and teamwork can also be a very important and useful skill for improving the development of all the skills.

The serious concern of engineering integration - the recognizing process of basic content knowledge with sound pedagogies required to fulfil engineering-oriented curriculum if engineering design - is the way for integration to occur and the teachers need to be completely set to include it into their teaching practice. 
Jonassen [9] stated that a design problem is an example of the most complicated and ambiguous goals kinds of problems that students face. For a student to learn the engineering design, the process needs more involvement more from the teacher which translates to not just entering the class and giving instructions according to a design process, but also explains and guides on how to use or make drawings [10]. According to De Miranda et al. [11], the big problem in this is what preparation and training should the teachers get for them to teach engineering design skills, particularly by the in-service teacher professional development program. Thus this research is investigated either the CDIO knowledge and skills that implemented in FBME and FKE together with the NALI [12] to provide the undergraduate students with the appropriate skills with in line with industry and technology development.

\section{Objectives}

The following are the objectives of this study:

1. To analyse CDIO knowledge for innovative capture project.

2. To analyse CDIO skills for innovative capture project.

\section{$4 \quad$ Methodology}

For the purpose of this study, a non-experimental approach was used to identify the impact of CDIO approach in terms of skills and knowledge for an innovative capstone project. A quantitative data survey of 5 Likert scale questionnaire was used to collect the numeric data among the students. The online survey of the same 5 Likert scale questionnaire using Google form was used specifically for the lecturers.

These researches focused on 58 third year students were selected, where 28 of them are from FBME and the remaining 30 students are from FKE. These students had the experience of conducting the innovation capstone project using the CDIO approaches.

A pilot test was firstly conducted where 5 students was chosen randomly from engineering department to answer the questionnaire. These students are those who also had the experience in conducting the CDIO approach. The Cronbach's Alpha for the reliability was then calculated. The results obtained by SPSS software recorded the Cronbach's Alpha of 0.865 , reflecting that the instrument has a high degree of reliability.

\section{$5 \quad$ Results and Findings}

The quantitative method survey with 5 Likert scales was used in this study. Table 1 displays the standard deviation, mean and median which were calculated using SPSS 18.0 to find which Item the students agree and do not agree with the most. There are two categories of students from different faculties, namely from the Faculty of Biosci- 
ences and Medical Engineering (FBME) and the Faculty of Electrical Engineering (FKE).The results and finding of this study are elaborated in sub-section as follows;

\subsection{Items for CDIO knowledge}

Table 1 listed the Items for students' survey of the CDIO knowledge in a capstone project

Table 1. Items for CDIO Knowledge

\begin{tabular}{|c|l|c|c|c|c|c|c|}
\hline \multirow{2}{*}{$\begin{array}{c}\text { No. } \\
\text { Item }\end{array}$} & & \multicolumn{3}{|c|}{ FBME } & \multicolumn{3}{c|}{ FKE } \\
\cline { 3 - 8 } & & Mean & Median & Std. & Mean & Median & Std. \\
\hline 1 & An interesting approach of learning. & 4.46 & 4.00 & 0.51 & 4.00 & 4.00 & 0.95 \\
\hline 2 & $\begin{array}{l}\text { Implement holistic development of } \\
\text { critical thinking and knowledge. }\end{array}$ & 4.64 & 5.00 & 0.56 & 4.00 & 4.00 & 0.74 \\
\hline 3 & Help student to think independently. & 4.54 & 5.00 & 0.69 & 4.27 & 4.00 & 0.74 \\
\hline 4 & $\begin{array}{l}\text { Help to improve student writing and } \\
\text { fluency oral defense. }\end{array}$ & 4.04 & 4.00 & 1.00 & 3.93 & 4.00 & 0.98 \\
\hline 5 & $\begin{array}{l}\text { Enables student to strengthen their } \\
\text { knowledge between practical and } \\
\text { theory in engineering course. }\end{array}$ & 4.50 & 4.50 & 0.51 & 4.27 & 4.00 & 0.78 \\
\hline 6 & $\begin{array}{l}\text { Students preferred the way of learn- } \\
\text { ing using CDIO. }\end{array}$ & 4.00 & 4.00 & 1.02 & 3.53 & 4.00 & 1.04 \\
\hline 7 & $\begin{array}{l}\text { It is less preferable than formal } \\
\text { lectures. }\end{array}$ & 2.48 & 2.00 & 1.42 & 3.76 & 4.00 & 1.21 \\
\hline
\end{tabular}

Table 1, shows the item statement about CDIO knowledge of the students for the mean value of item 1 until 7. Item 2 and 3 shows the value of median were different for both faculties. For FBME the median and mean value were 5.00, 4.64 (Std.=0.56) and $4.54(\mathrm{Std} .=0.69)$ respectively which mean most students strongly agreed with the statements but for FKE the mean and median values were $4.00($ Std. $=0.74)$ for item 2 and the median value was 4.00 with mean value was $4.27(\mathrm{Std} .=0.74)$ for the item 3 . That means, most of students agreed with the statements. The item 1, 4, and 6 the median values for the both faculties was the same which 4.00 with different values of mean and standard deviation except item 5 which that the median values was 4.50. But, we can assume most students from both faculties were agreed with that statement. Finally, for the item 7 which that there were different values of median in both faculties which from FBME, the median value was 2.00 and the mean value was 2.48 (Std.=1.42) which mean most of students disagreed with the statement. But, for FKE the median value was 4.00 and mean $3.76(\mathrm{Std} .=1.21)$ which mean most of student agreed with the statement.

\subsection{Items for CDIO skills}

Table 2 listed the Items for students' survey of the CDIO skills in a capstone project. 
Table 2. Items for CDIO Skills

\begin{tabular}{|c|l|c|c|c|c|c|c|}
\hline \multirow{2}{*}{$\begin{array}{c}\text { No. } \\
\text { Item }\end{array}$} & & \multicolumn{3}{|c|}{ FBME } & \multicolumn{3}{c|}{ FKE } \\
\cline { 2 - 7 } & & Mean & Median & Std. & Mean & Median & Std. \\
\hline 8 & $\begin{array}{l}\text { Improved student team-working skills. } \\
\text { (Teamwork skill) }\end{array}$ & 4.82 & 5.00 & 0.39 & 4.23 & 4.00 & 0.90 \\
\hline 9 & $\begin{array}{l}\text { Improved student problem solving } \\
\text { skills. (Problem solving) }\end{array}$ & 4.57 & 5.00 & 0.50 & 4.10 & 4.00 & 0.76 \\
\hline 10 & $\begin{array}{l}\text { Enjoyable and improve the social } \\
\text { skills than formal lectures (Communi- } \\
\text { cation skill) }\end{array}$ & 4.29 & 4.00 & 0.85 & 4.03 & 4.00 & 1.03 \\
\hline 11 & $\begin{array}{l}\text { Sessions enable student to fully partic- } \\
\text { ipate as a team member. (Teamwork } \\
\text { skill) }\end{array}$ & 4.61 & 5.00 & 0.50 & 3.93 & 4.00 & 0.87 \\
\hline 13 & $\begin{array}{l}\text { Develop student responsibility, toler- } \\
\text { ance, ethics, friendship, and punctuali- } \\
\text { ty (Communication skill). }\end{array}$ & 4.64 & 5.00 & 0.49 & 4.00 & 4.00 & 0.59 \\
\hline 14 & $\begin{array}{l}\text { Student can design, implement and } \\
\text { innovate their product in capstone } \\
\text { project. (Problem solving) }\end{array}$ & 4.57 & 5.00 & 0.69 & 4.07 & 4.00 & 0.78 \\
\hline 15 & $\begin{array}{l}\text { Student can produce a final product or } \\
\text { system in given time. (Problem solv- } \\
\text { ing). }\end{array}$ & 4.25 & 4.50 & 0.89 & 4.23 & 4.00 & 0.77 \\
\hline $\begin{array}{l}\text { Student can improve their communi- } \\
\text { cation skills. (Communication skill) }\end{array}$ & 4.25 & 4.00 & 0.84 & 3.73 & 4.00 & 1.26 \\
\hline $\begin{array}{l}\text { Students in group can cooperate well } \\
\text { and helpfulness each other. (Team- } \\
\text { work skill) }\end{array}$ & 4.25 & 4.50 & 0.88 & 4.00 & 4.00 & 0.75 \\
\hline
\end{tabular}

Table 2, shows the statement about the CDIO approach that related to the skill for the mean value of item 8 until 15. From the item 8, 9, 11, 12 and 13 the median values for FBME are the same which 5.00 with the different values of mean which are 4.82 $($ Std. $=0.39), 4.57($ Std. $=0.50), 4.61($ Std. $=0.50), 4.64($ Std. $=0.49)$ and $4.57($ Std. $=0.69)$ respectively, that mean most of the students strongly agreed with that statements. But, the median results shows differently in FKE where the median value was 4 which most students agreed with the statements with the different values of mean which were $4.23($ Std. $=0.90), 4.10($ Std. $=0.76), 3.93($ Std. $=0.87), 4.00($ Std. $=0.59)$ and 4.07 (Std. $=0.78)$ respectively. The item 1015 and 16 shows that the medium value from both faculties are same which 4.00 except for the item 14 and 16 were 4.50 for FBME, but we assumed that most students agreed with the statement with the different values of mean. For FBME the mean values were 4.29 (Std.=0.85), 4.25 $(\mathrm{Std} .=0.89), 4.25(\mathrm{Std} .=0.84)$ and $4.25(\mathrm{Std} .=0.88)$ respectively while for FKE the mean values were $4.03($ Std. $=1.03), 4.23($ Std. $=0.77), 3.73($ Std. $=1.26)$ and 4.00(Std. $=0.75)$.

\section{Discussion}

Table 1 shows the mean for item 1 until 7 and it was about the CDIO approach that related to the knowledge between student FBME and students FKE. Item 1, 2, 3 and 5 
shows the same results of mean for the students of both faculties which is they agreed with these statements. For the Item 2 and 3 with the statements "Implement holistic development of critical thinking and knowledge," and "Help student to think independently," shows that the students FBME strongly agreed with these statements, however, the results show differently for students FKE for item 2 and 3 that the students only agreed with these statements which the engineering education advancement highlights the enlightenment of the students' understanding where by choosing method engineering as all of the materials that have the ability to portray the ability of engineering education innovation to be practiced [13].

Item 7 shows that students FBME disagreed about the statement "It less preferable than formal lectures". The mean result shows differently for students FKE which was the students only agreed with the item 7 . The average mean for students FBME was 4.094 and for students FKE was 3.966. The average mean for students FBME was higher that the students FKE, but overall the students both faculties agreed with this second objectives. In this section from the UTM NALI [12] focused on designimplement practices and incorporated education involvements. So that, both faculties had followed the Standard 5 which is design-implement practices and Standard7 which is incorporated education involvements.

Table 2 shows the mean for item 8 until 16 and it was about the CDIO skills between students FBME and FKE. There were three skills that the researcher required to focus which consists of teamwork, problem solving, and communication skills. These three skills or element are really important when students apply the CDIO in their capstone project. For the item 8,11 and 16 that focused on the teamwork skills which was "Improved student team working skills," "Sessions enable student to fully participate as a team member," and "Students in group can cooperate well and helpfulness each other", respectively shows most of students from FBME strongly agreed with these statements. This is because of teamwork skills was very important to the development of an engineering project which involve a professional in a multidisciplinary approach in a real working environment and also the tool to enhance learning and development of these skills [14] Besides that, for students FKE most of the students only agreed with these statements.

The second skill was about the problem solving which included in item 9,13 and 14 with the statement, "Improved student problem solving skills", "Student can design, implement and innovate their product in capstone project" and "Student can produce a final product or system in given time". The mean result shows most of students FBME strongly agreed with this statement and for students FKE most students only agreed with this statement where according to Rahman [15] in which the students learn to solve the problems and complete the project that the students followed the stage of CDIO.

For the third skill was about communication skill which item 10, 12 and 15 with the statement "Enjoyable and improve the social skills than formal lectures", "Develop student responsibility, tolerance, ethics, friendship, and punctuality", and "Student can improve their communication skills." The result shows that students from both faculties were agreed with this statement. Heitmann \& Vinther [16] stated that the communication skill was not only for handy but they were also important components 
to achieve success and to survive in the real life environment. The average mean for the students FBME in this section was 4.5 and for students FKE was 4.04 which means the average mean for students FBME was higher than average mean for students FKE. Overall, students from both faculties agreed with this second objectives. In this section from the UTM NALI [12] focused on design-implement experiences and ideas in a bid to improve the interpersonal, intrapersonal, and system building skills of teaching faculty. So that, both faculties had follows the UTM CDIO practice for the Standard5 which create instrument experiences and Standard 9 which is improvement of faculty talents competence.

\section{Conclusion}

As conclusion, in undergraduate engineering courses nowadays have growing tension between two needs, firstly there is the increasing of disciplinary information consistently where all learners need to grasp and secondly the engineering students must possess a variety of skills that the researcher stressed out such as teamwork, problem solving, and communication that help them to employability and adapt with real world engineering problems. Besides that, from the analysis result which is from students' surveys about the CDIO knowledge and skills in capstone project, it can be seen that the effectiveness of CDIO very successful when correctly adopted and implemented in an undergraduate engineering course. This is because the average mean for all objectives indicated that majority of respondents agreed that the proper implementation of CDIO knowledge and skills in capstone project is important in engineering education. As a results, it will yielded students with the knowledge and employment skills as requested by the employer.

\section{Acknowledgements}

Authors would like to thank Ministry of Higher Education Malaysia for the Fundamental Research Grant Scheme (FRGS) of this project with Vote number 4F922.

\section{$9 \quad$ References}

[1] Sheppard, S., K. Macatangay, A. Colby, and W. M. Sullivan. 2009. Educating Engineers: Designing for the Future of the Field. San Francisco, CA: Jossey-Bass

[2] Azli, N.A, Jambari, H (2017). Quality of Engineering Graduates of a Malaysian Public University. 7th World Engineering Education Forum, 420-423. https://doi.org/10.1109/weef.2017.8467031

[3] Shuman, L. J., Besterfield-Sacre, M., \& McGourty, J. (2005). The ABET "professional skills" - can they be taught? Can they beassessed? Journal of Engineering Education, 94(1), 41-55. https://doi.org/10.1002/j.2168-9830.2005.tb00828.x

[4] Trevelyan, J. (2008, July). Real engineering is not what you learned at school......or is it? Paper presented at the Research in Engineering Education Symposium (REES) 2008, Davos, Switzerland. 
Short Paper-Impacts of Conceive-Design-Implement-Operate Knowledge and Skills for Innovative ...

[5] Duderstadt, J. J. (2008). Engineering for a changing world: A roadmap to the future of engineering practice, research, and education. Ann Arbor, MI: University of Michigan.

[6] Hanifah Jambari, Nurul Amalin Razali, Ishak Taman, Nur Hazirah Noh@Seth, Sharifah Osman, Jamilah Ahmad, Norjulia Mohamad Nordin, \& Mohd Rustam Mohd Rameli (2018). Conceive-Design-Implement-Operate (CDIO) Approach for an Innovative Capstone Project. Journal of Technical Education and Training, 10(2), 82-91. https://doi.org/10.30880/jtet.2018.10.02.008

[7] Zhuang, Z.M., Tang, Y.J., \& Shen, M.F. (2008). Cornerstone conceive for electronic engineering fresher-experience with CDIO innovation and project. Proceedings of the 4th International CDIO Conference, Hogeschool Gent, Gent, Belgium, June 16-19

[8] Crawley, E.F., Malmqvist, J., Östlund, S., Brodeur, D.R. \& Edström, K. (2014). Rethinking Engineering Education. Cham, Switzerland: Springer International Publishing. https://doi.org/10.1007/978-3-319-05561-9

[9] Jonassen, D. H. (2000). Toward a design theory of problem solving. ETR\&D, 48(4), 6385 .

[10] Warner, S. (2003). Teaching design: Taking the first steps. The Technology Teacher, 62(A), 7-11.

[11] De Miranda, M. A., Troxell, W., Siller, T. J., \& Iversen, E. (2008). Preparing technology teachers to infuse engineering into technology education: Pre-service, professional development, and outreach. In R. L. Custer, \& T. L. Erekson. Engineering and technology education. 57th Yearbook, Council on Technology Teacher Education (pp. 133-157). Woodland Hills, CA: Glencoe.

[12] Nali (2016). A Guide to New Academia Learning Innovation. UTM Lead Johor Bahru.

[13] Wei Yi, Zhang Yuanming, Wan yi (2011). "The Intertial Thinking Based on CDIO Mode of Engineering Education," Journal of Modern Information, No.4, pp.112-113

[14] Poh-Hui Chua, Sin-Moh Cheah \& Mark Nivan Singh (2011). "Integrating CDIO Skills into a Statistics Module," 7th International CDIO Conference, pp.1-2.

[15] Rahman R A, Zan M M M, Abidin H Z, Kassim M, Yahaya (2010) Transforming Engineering Education: Creating Interdisciplinary Skills for Complex Global Environments, 2010 IEEE 1-18. https://doi.org/10.1109/tee.2010.5508830

[16] Heitmann, G. \& Vinther, O. (2009). Paradigm change in engineering education through the last half century. Paper presented at the SEFI 37th Annual Conference 2009, Rotterdam, NL.

\section{Authors}

Hanifah Jambari, Nurul Amalin Razali, Nur Hazirah Seth@Noh, Nurul Aini Mohd Ahyan, Mohamad Rasidi Pairan, Jamilah Ahmad, and Sharifah Osman are with the Faculty of Social Sciences and Humanities, Technical and Engineering Education, Universiti Teknologi Malaysia (hanifah-j@utm.my).

Article submitted 2019-03-16. Resubmitted 2019-05-03. Final acceptance 2019-05-14. Final version published as submitted by the authors. 